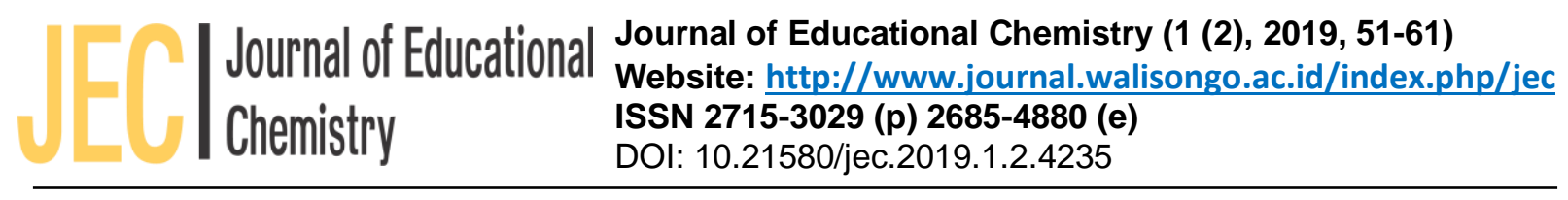

\title{
Pengembangan Petunjuk Praktikum Berbasis Green Chemistry Pada Materi Stoikiometri Kelas X
}

\author{
Siska Aditya Yuniar1, Muhammad Zammi², Ervin Tri Suryandari ${ }^{3}$ \\ ${ }^{1}$ Madrasah Aliyah Miftahul Akhlaqiyah Semarang \\ 2,3Pendidikan Kimia Universitas Islam Negeri Walisongo Semarang \\ 1E-mail: siskaadityayuniar@yahoo.com
}

\begin{abstract}
Research on the development of green chemistry-based practical instructions on stoichiometry material is based on students caracteristics who prefer practicum methods, but in schools do not yet have practicum instructions that can adjust the time of practicum with school hours. The development method used is the ADDIE method which consists of analysis, design, development, implementation, and evaluation. The product was validated by two material expert lecturers and two media expert lecturers, then an openness test was conducted by the teacher and students, and distributed to small classes. The openness test subjects were one chemistry teacher and three students of class XI IPA of SMA N 7 Semarang, and subjects of small class trials were nine students of class XI IPA of SMA N 7 Semarang. The results of the expert validation assessment get a validity index of 0.902 with a very high category, and the validation value of the media expert gets an index of validity of 0.984 with a very high category. In the openness test by the teacher obtained a very good category with a percentage of $96.47 \%$. In the openness test by students obtained a percentage of $95.83 \%$ with a very good category. The response of students participations in the category is very good with a percentage of $94.29 \%$.
\end{abstract}

Keywords: practical guidance, green chemistry, stoichiometry 


\begin{abstract}
Abstrak
Penelitian pengembangan petunjuk praktikum berbasis green chemistry pada materi stoikiometri dilandaskan pada karakteristik peserta didik yang lebih menyukai metode praktikum, namun di sekolah belum memiliki petunjuk praktikum yang dapat menyesuaikan waktu pelaksanaan praktikum dengan jam pelajaran di sekolah. Metode pengembangan yang digunakan adalah metode ADDIE yang terdiri dari tahap analyze, design, development, implementation, dan evaluations. Produk divalidasi oleh dua dosen ahli materi dan dua dosen ahli media, kemudian dilakukan uji keterbacaan oleh guru dan peserta didik, dan diuji cobakan pada kelas kecil. Subjek uji keterbacaan yaitu satu guru mata pelajaran kimia serta tiga peserta didik kelas XI IPA SMA N 7 Semarang, dan subjek uji coba kelas kecil yaitu sembilan peserta didik kelas XI IPA SMA N 7 Semarang. Hasil penilaian validasi ahli materi didapatkan indeks validitas 0,902 dengan kategori sangat tinggi, dan penilaian validasi ahli media mendapat indeks validitas sebesar 0,984 dengan kategori sangat tinggi. Pada uji keterbacaan oleh guru didapatkan kategori sangat baik dengan presentase sebesar 96,47\%. Pada uji keterbacaan oleh peserta didik didapatkan presentase sebesar 95,83\% dengan kategori sangat baik. Respon peserta didik memperlihatkan kategori sangat baik dengan presentase sebesar $94,29 \%$.
\end{abstract}

Kata Kunci: petunjuk praktikum, green chemistry, stoikiometri

\title{
Pendahuluan
}

Ilmu kimia merupakan ilmu yang mempelajari tentang komposisi, struktur, sifat materi dan perubahan suatu materi, serta energi yang menyertai nya. Ilmu kimia dikembangkan melalui kajian empiris yang pembahasan di dalamnya diperoleh melalui kerja ilmiah. Bersumber pada hasil observasi diketahui bahwa 90\% peserta didik menganggap kimia adalah mata pelajaran yang sulit, ini tidak terlepas dari salah satu ciri ilmu kimia menurut Middlecamp (Yakina, 2017) yaitu sebagian besar ilmu kimia bersifat abstrak. Berdasarkan observasi yang dilakukan di SMA N 7 Semarang pada tanggal 23 Juli hingga 16 September 2018, diketahui peserta didik cenderung pasif dalam proses belajar karena pembelajaran kimia masih didominasi oleh metode ceramah dan didapati 52

Copyright (C) 2019 JEC | ISSN 2715-3029 (p) 2685-4880 (e)

Volume 1, Nomor 2, 2019 bahwa metode praktikum tidak pernah digunakan dalam proses pembelajaran. Tidak dilaksanakan-nya kegiatan praktikum karena adanya keterbatasan waktu yang tersedia dalam pembelajaran kimia memberikan dampak atau tantangan bagi guru dalam pelaksanaan pembelajran kimia dengan melibatkan praktikum durasi praktikum. Kesulitan di dalam pembelajaran kimia dengan melibatkan praktikum menjadi suatu permasalahan yang utama di SMA N 7 Semarang dan mungkin juga dialami oleh sekolah lainnya. Dalam implementasi kurikulum 2013, pelaksanaan praktikum menjadi satu hal penting untuk meningkatkan kualitas pembelajaran dimana peserta didik tidak hanya diarahkan pada pendekatan sikap dan pengetahuan tetapi juga 
diarahkan pada pendekatan keterampilan (Nazilla dkk, 2017).

Hal senada disampaikan oleh Zhong (2014) bahwa pelajaran kimia tidak dapat dipisahkan dengan praktikum karena praktikum memiliki peranan penting pada penguasaan materi pembelajaran hingga pengembangan kemampuan berpikir ilmiah. Redhana (2014:148) dalam pembelajaran kimia, menyatakan bahwa pembelajaran dengan metode praktikum tidak dapat digantikan oleh metode pembelajaran lainnya seperti penggunaan animasi dan video.

Pentingnya praktikum dalam pembelajaran kimia didukung dengan hasil pengisian angket kebutuhan oleh peserta didik bahwa peserta didik lebih menyukai pembelajaran menggunakan metode praktikum karena dianggap dapat membantu dalam memahami materi. Metode ceramah yang digunakan oleh guru membuat proses pembelajaran kimia terkesan menjemukan mengakibatkan peserta didik sering merasa mengantuk dan tidak mendengarkan ketika guru menerangkan. Banyak ahli pendidikan memandang bahwa pendidikan adalah modal utama untuk membawa suatu bangsa atau negara ke arah modernisasi dan kemajuan (A'la, 2012). Oleh karena itu untuk menentukan kualitas sebuah pendidikan, pemilihan metode pembelajaran menempati posisi yang sangat penting.

Salah satu metode pembelajaran yang dapat diterapkan sebagai penyelesaian masalah yang dihadapi peserta didik adalah dengan pelaksanaan metode praktikum yang efektif dan efisien. Ural (2016) menyebutkan bahwa tujuan dari kegiatan praktikum adalah meningkatkan pengetahuan teori dengan pemecahan masalah dan proses sains. Dibandingkan dengan metode lain, metode praktikum memiliki satu kelebihan. Menurut Balram (2017:3) kegiatan praktikum memberikan kesempatan peserta didik untuk memperoleh pengetahuan episode. Pengetahuan episode adalah pengetahuan yang memiliki retensi tinggi sehingga dapat diingat lebih lama dan lebih mudah untuk digunakan atau diingat kembali (Mulyani, 2003). Metode praktikum dapat digunakan untuk membantu siswa dalam memahami materi kimia yang telah diajarkan. Dengan metode ini peserta didik melakukan dan mengalami sendiri, mengikuti proses, mengamati obyek, menganalisis, membuktikan dan menarik kesimpulan suatu obyek, keadaan dan proses dari materi yang dipelajari tentang gejala alam dan interaksinya sehingga dapat menjawab pertanyaan yang didapatkan melalui pengamatan induktif (Djamarah \& Zain, 2002). Balram (2017) dan Ojediran, dkk (2014) melaporkan bahwa hasil belajar peserta didik dengan menggunakan metode praktikum mengalami peningkatan lebih tinggi dibandingkan dengan peserta didik yang menggunakan metode konvensional atau ceramah. Hal senada juga disebutkan Kandamby (2019) bahwa kegiatan praktikum yang dilakukan di laboratorium merupakan metode yang memberikan pengaruh terhadap keberhasilan peserta didik dalam pembelajaran kimia.

Dalam kegiatan praktikum selain alat dan bahan, hal lain yang harus dipersiapkan oleh guru adalah petunjuk praktikum. Petunjuk praktikum dapat menunjang kegiatan praktikum agar berjalan efektif. Menurut Rismawati (2012) petunjuk praktikum dapat diperoleh dengan cara mengadopsi petunjuk praktikum dari buku paket yang telah ada atau mengembangkan sendiri petunjuk praktikum yang sederhana dan lebih mudah dipahami. Berdasarkan wawancara yang telah dilakukan dengan guru pengampu mata pelajaran kimia di SMA N 7 Semarang, diketahui bahwa peserta didik belum memiliki petunjuk praktikum sebagai pedoman pelaksanaan kegiatan praktikum sehingga menghambat peserta didik untuk terlibat aktif dalam proses pembelajaran (Duratun, wawancara 16 Januari 2019). Hal tersebut kemudian dipandang perlu adanya diperlukan penyusunan petunjuk praktikum kimia untuk menunjang kegiatan proses belajar dengan metode praktikum yang efektif dan efisien. 
Dibalik kelebihannya, metode praktikum merupakan salah satu kegiatan penghasil limbah yang jika tidak diolah dapat berdampak negatif bagi lingkungan dalam jangka pendek maupun jangka panjang. Jangka panjang yang dimaksud yaitu bersifat antar generasi karena dampak yang ditimbulkan terutama pada limbah kimia tidak hanya berdampak pada orang yang terpapar tetapi dapat mengakibatkan keturunannya mengalami hal serupa (Habibi dan Marwan, 2018). Luasnya dampak ini adalah efek dari karakteristik limbah yang berukuran mikro (Mattsson, dkk, 2015). Achmad (2011) dan Mackenbach (2007) turut mengatakan bahwa penggunaan bahan kimia yang terus meningkat untuk menunjang aktivitas manusia berakibat pada munculnya masalah-masalah lingkungan yang dapat mengancam kehidupan dunia.

Oleh karena itu jawaban dari masalah lingkungan yang meningkat dari kegiatan penghasil limbah seperti kegiatan praktikum adalah dengan penerapan prinsip Green Chemistry (Anastas, 2018). Green chemistry adalah suatu konsep teknologi kimia inovatif yang mengurangi penggunaan maupun produksi bahan kimia berbahaya, pembuatan dan penggunaan produk kimia (Anastas \& Warner ,1998). Beberapa dari 12 prinsip Green Chemistry dapat diterapkan dalam pembelajaran kimia, di antaranya (1) pencegahan terbentuknya limbah, (2) perancangan produk yang lebih aman, (3) efisiensi energi, (4) penggunaan bahan baku terbarukan, (5) pencegahan polusi, dan (6) meminimalkan potensi kecelakaan kerja (Hazel, 2002). Namun, kegiatan praktikum pada pembelajaran kimia kerap dilakukan dengan menggunakan bahan kimia yang tidak sesuai dengan prinsip-prinsip Green Chemistry (Duratun, wawancara 16 Januari 2019). Penerapan prinsip Green Chemistry dapat dilakukan dengan penyusunan petunjuk praktikum berbasis Green Chemistry.

\section{4}

Copyright (C) 2019 JEC | ISSN 2715-3029 (p) 2685-4880 (e) Volume 1, Nomor 2, 2019
Penerapan prinsip Green Chemistry pada petunjuk praktikum dapat membantu peserta didik dalam memahami materi yang dianggap sulit seperti materi yang dibahas dengan melibatkan perhitungan dalam penyelesaiannya, dengan menggunakan bahan ramah lingkungan yang dapat dijumpai di lingkungan sekitar. Penyelesaian perhitungan dalam beberapa bab seperti kesetimbangan, laju reaksi, dan larutan asam basa menggunakan dasar stoikiometri. Chang (2005) mengemukakan bahwa stoikiometri adalah ilmu yang mempelajari kuantitas produk dan reaktan dalam reaksi kimia. Hal tersebut menjadikan materi stoikiometri melibatkan cukup banyak konsep matematika didalamnya. Dengan dasar itulah materi Stoikiometri menjadi sangat penting untuk dipahami oleh peserta didik karena konsep pada materi stoikiometri menjadi prasyarat untuk mempelajari pokok bahasan lain dalam pembelajaran kimia. Namun, dari hasil observasi yang telah dilakukan materi stoikiometri dirasa sangat sulit dikarenakan materi tersebut cukup rumit, melibatkan banyak konsep matematika dalam pemecahan soal perhitungannya, serta waktu penyampaian yang terbatas. Selain itu materi stoikiometri dirasa sulit oleh peserta didik juga karena dalam pembelajaran materi stoikiometri peserta didik berperan sebagai penerima informasi dan tidak terlibat secara aktif dalam pembelajaran. Berdasarkan uraian di atas, maka peneliti tertarik untuk mengembangkan Petunjuk Pratikum Berbasis Green Chemistry pada materi Stoikiometri yang dipandang sebagai suatu langkah kecil menuju pendidikan untuk pembangunan berkelanjutan.

\section{Metode Penelitian}

Penelitian ini merupakan jenis penelitian R\&D (Research and Development), di mana dihasilkan produk berupa buku petunjuk praktikum kimia berbasis green chemistry untuk SMA/MA pada materi stoikiometri. Dalam 
penelitian ini digunakan model pengembangan ADDIE (Analyze, Design, Development or Production, Implementation or Delivery, and Evaluations) yang dikembangkan oleh Dick and Carry (1996).

Subjek pada penelitian ini yaitu peserta didik kelas XI IPA 3 SMA N 7 Semarang. Pada uji keterbacaan dilaksanakan dengan tiga perwakilan peserta didik. Untuk menyaring respons peserta didik terhadap petunjuk praktikum dilakukan dengan uji kelas kecil sebanyak sembilan peserta didik di antaranya tiga peserta didik yang memiliki kemampuan tinggi, tiga peserta didik dengan kemampuan sedang, dan tiga peserta didik dengan kemampuan rendah.

Pada pengembangan dan penelitian ini jenis validitas dalam proses validasi yang digunakan adalah content validity atau validitas isi. Pada penentuan indeks validitas (V) pada setiap indikator digunakan indeks yang dirumuskan oleh Aiken sebagai berikut : (Retnawati, 2016)

$$
\mathrm{V}=\frac{\Sigma s}{[n(c-1)]}
$$

Keterangan:

$$
\begin{array}{ll}
\mathrm{s} & =\mathrm{r}-\mathrm{lo} \\
\mathrm{r} & =\text { skor yang diberikan validator } \\
\mathrm{lo} & =\text { skor terendah dalam penilaian (dalam } \\
& \text { hal ini lo }=1 \text { ) } \\
\mathrm{n} & =\text { jumlah validator } \\
\mathrm{c} & =\text { skor tertingi dalam penilaian (dalam } \\
& \text { hal ini } \mathrm{c}=5 \text { ) }
\end{array}
$$

Indeks validitas (V) yang diperoleh kemudian diintepretasikan dengan kriteria validitas seperti pada Tabel 1.

Tabel 1 kriteria penilaian validitas isi

\begin{tabular}{cc}
\hline $\begin{array}{c}\text { Rentang } \\
\text { nilai V }\end{array}$ & Tingkat Validitas \\
\hline $0,80-1,00$ & Sangat tinggi \\
$0,60-0,80$ & Tinggi \\
$0,40-0,60$ & Sedang \\
$0,20-0,40$ & Rendah \\
$0,00-0,20$ & Sangat rendah \\
\hline
\end{tabular}

\section{Hasil Penelitian dan Pembahasan}

Hasil uji dengan metodologi penelitian ADDIE pada penelitian ini adalah sebagai berikut:

\section{Analyze (Analisis)}

a. Analisis permasalahan

Permasalahan yang dijumpai diantaranya yaitu, peserta didik kerap tidak dapat berkonsentrasi dengan baik saat proses belajar mengajar di kelas, kemudian peserta didik kerap mengantuk ketika guru menerangkan. Berdasarkan hasil pengisisan angket kebutuhan didapatkan sebesar 75\% peserta didik merasa kesulitan untuk memahami materi stoikiometri.

b. Menentukan tujuan pembelajaran

Tujuan pembelajaran pada penelitian ini ditentukan dengan merujuk pada Kompetensi Dasar (KD) pada materi stoikiometri yang disesuaikan dengan silabus mata pelajaran kimia Sekolah Menengah Atas (SMA) atau Madrasah Aliyah (MA) kurikulum 2013 revisi.

c. Analisis peserta didik

Analisis peserta didik dilakukan dengan penyebaran angket. Data yang diperoleh sebesar $90 \%$ peserta didik menganggap bahwa kimia merupakan mata pelajaran yang sulit. Peserta didik memahami materi serta konsep baru dengan menghubungkannya dengan sesuatu yang mereka ketahui sebelumnya. Oleh karenanya diperlukan metode pembelajaran yang mampu mendukung peserta didik dalam proses pembelajaran kimia. Sebesar 100\% peserta didik menyukai pembelajaran kimia dengan metode praktikum karena metode praktikum dapat membantu peserta didik dalam memahami materi yang diberikan.

d. Analisa sumber daya yang diperlukan 
Berdasarkan observasi yang telah dilakukan, peneliti mendapati bahwa sumber daya yang dimiliki oleh sekolah adalah laboratorium kimia yang dapat digunakan dalam kegiatan praktikum pada proses pembelajaran.

\section{Design (Perancangan)}

Tahap design pada penelitian ini dibagi menjadi beberapa langkah, di antaranya:

a. Menyusun tujuan pengembangan

Tujuan pengembangan pada penelitian ini harus memiliki kesesuaian dengan tujuan pembelajaran. Tujuan pengembangan yang ingin dicapai pada penelitian ini yaitu untuk menghasilkan buku pegangan dalam pelaksanaan praktikum pada materi stoikiometri untuk membantu peserta didik mencapai tujuan pembelajaran secara maksimal. Tujuan pengembangan lainnya adalah untuk memberikan informasi baru terkait pelaksanaan praktikum kimia dengan penerapan prinsip green chemistry.

b. Menghasilkan strategi pengujian Strategi pengujian yang disusun oleh peneliti dalam petunjuk praktikum berbasis green chemistry yaitu soal pada analisa data yang dapat menjadi bahan uji bagi peserta didik yang telah mempelajari materi stoikiometri.

\section{Development (Pengembangan)}

Tahap Development terbagi menjadi beberapa langkah, di antaranya:

a. Menghasilkan konten

Pada langkah ini disusun konten yang merupakan strategi pembelajaran. Strategi pembelajaran ini akan digunakan untuk menyusun konsep yang menjadi kerangka kerja produk guna mencapai tujuan pembelajaran.

b. Mengembangkan media
Langkah pengembangan media akan menyajikan gambaran kasar konten pada produk yang telah disusun pada langkah sebelumnya. Pengembangan media pada metodologi penelitian ADDIE perlu memperhatikan dua hal yaitu secara konsep dan teori. Konsep atau skema pada pengembangan media dalam penelitian ini adalah 1) sampul, 2) kata pengantar, 3) daftar isi, 4) tata cara petunjuk praktikum, 5) tata tertib labiratorium kimia, 6) simbol keselamatan kerja yang terdiri dari alat pelindung diri (apd) serta kegunaannya, alat keselamatan kerja serta kegunaannya, dan simbol tanda bahaya serta artinya, 7) petunjuk penyusunan laporan praktikum, 8) alat praktikum kimia dan kegunaannya, 9) daftar pustaka, 10) tentang penulis. Teori atau materi yang ada pada petunjuk praktikum berbasis green chemistry adalah

1) Pada petunjuk pratikum mencakup tiga praktikum yang bersumber dari jurnal, karya tulis ilmiah, serta buku yang disusun dengan mempertimbangkan waktu pelaksanaan kegiatan praktikum agar dapat disesuaikan dengan jam pelajaran mata pelajaran kimia yang tersedia. Teori pada media yang dihasilkan pada peneliti diantaranya:

a) Praktikum menentukan kadar zat, penentuan pereaksi pembatas, dan penentuan rumus senyawa hidrat dengan disertai pengimplementasian beberapa prinsip green chemistry diantaranya pencegahan terbentuknya limbah, perancangan produk yang lebih aman, efisiensi energi, penggunaan bahan terbarukan, 
pencegahan polusi, dan meminimalkan potensi kecelakaan kerja. Pada setiap praktikum disertai dengan kolom prinsip green chemistry yang diterapkan.

b) Pembahasan materi singkat yang disertai dengan apersepsi. Pada petunjuk praktikum dilengkapi dengan lembar analisa data pada setiap praktikum.

c) Penjelasan tentang apa itu green chemistry dengan disertai contoh studi kasus pada setiap penjelasan untuk memudahkan peserta didik membedakan antara prinsip satu dengan prinsip yang lainnya.

d) Format laporan praktikum disertai penjelasan singkatnya.

Susunan konsep dan materi pada produk seperti pada gambar yang dapat dilihat pada Gambar 1

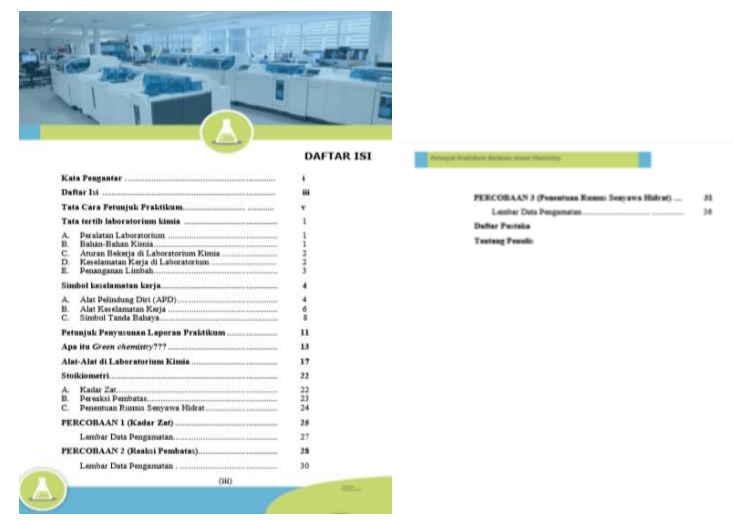

Gambar1 Daftar isi

Setelah pengembangan media selanjutnya dilakukan validasi untuk mengetahui kelayakan produk yang telah dikembangkan. Hasil validasi ahli materi dan media dapat dilihat pada Grafik 2.

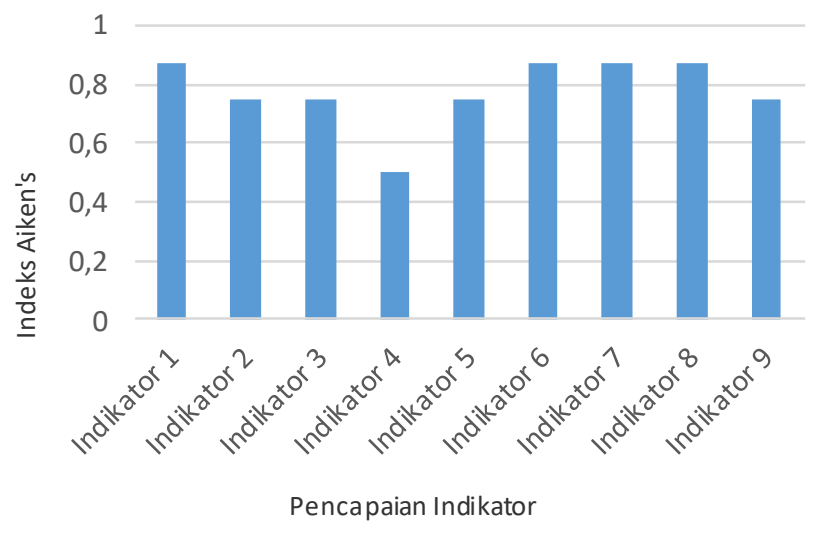

Grafik 1 Hasil uji validasi isi ahli materi

Keterangan:

Indikator 1: kesesuaian dengan KI, KD

Indikator 2: kesesuaian dengan kebutuhan peserta didik

Indikator 3 : kontruksivisme apersepsi

Indikator 4 : keakuratan materi

Indikator 5 : kejelasan informasi

Indikator 6 : keterbacaan

Indikator 7 : penyajian pembelajaran

Indikator 8 : pendukung penyajian

Indikator 9 : penerapan prinsip green chemistry

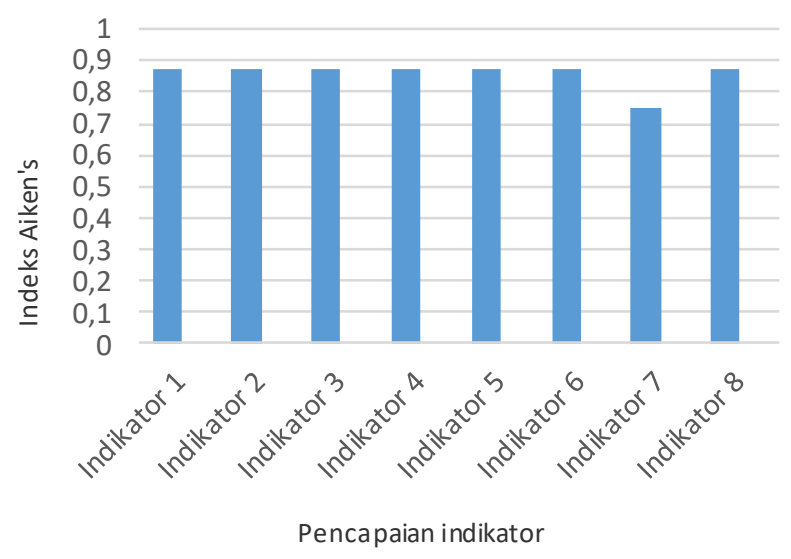

Grafik 2 Hasil uji validasi isi ahli media

Keterangan :

Indikator 1 : penyajian petunjuk praktikum

Indikator 2 : ukuran buku

Indikator 3 : tata letak kulit buku 
Indikator 4 : tipografi cover buku

Indikator 5 : ilustrasi kulit buku

Indikator 6 : tata letak isi buku

Indikator 7 : tipografi isi buku

Indikator 8 : kualitas tampilan

Berdasarkan Grafik 3 nilai $V$ yang didapatkan pada indikator 1, 2, 3, 4, 5, dan 6 (penyajian petunjuk praktikum, ukuran buku, tata letak kulit buku, tipografi cover buku, ilustrasi kulit buku, dan tata letak isi buku) adalah 0,875 dengan tingkat validitas sangat tinggi. Pada indikator 7 (tipografi isi buku) nilai $\mathrm{V}$ nya adalah 0,75 dengan tingkat validitas tinggi. Pada indikator 8 (kualitas tampilan) nilai V nya 0,875 dengan tingkat validitas sangat tinggi.

c. Melakukan uji coba

Pada uji keterbacaan oleh peserta didik diperoleh 95,833\% dengan tingkat keterbacaan sangat baik. Hasil uji keterbacaan oleh peserta didik tiap item penilaian pada langkah ini dapat dilihat pada Grafik 3.

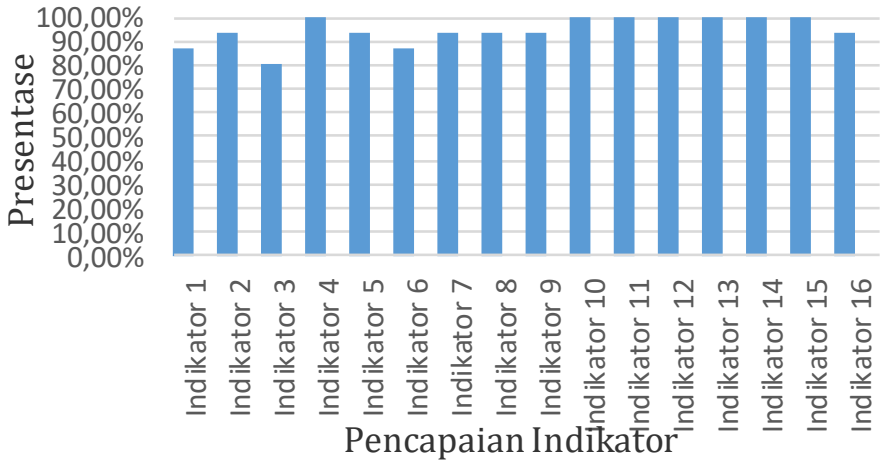

Grafik 3 Hasil uji keterbacaan oleh peserta didik

58

Copyright (C) 2019 JEC | ISSN 2715-3029 (p) 2685-4880 (e)

Volume 1, Nomor 2, 2019

\section{Implementation (Implementasi)}

Pada tahap ini dilaksanakan kegiatan praktikum oleh peserta didik menggunakan produk yang telah dikembangkan dan selanjutnya dilaksanakan pengumpulan respon peserta didik terhadap petunjuk praktikum berbasis green chemistry pada materi stoikiometri yang telah dikembangkan peneliti. Respon peserta didik yang diperoleh dalam kategori sangat baik dengan jumlah presentase rerata $94,29 \%$.

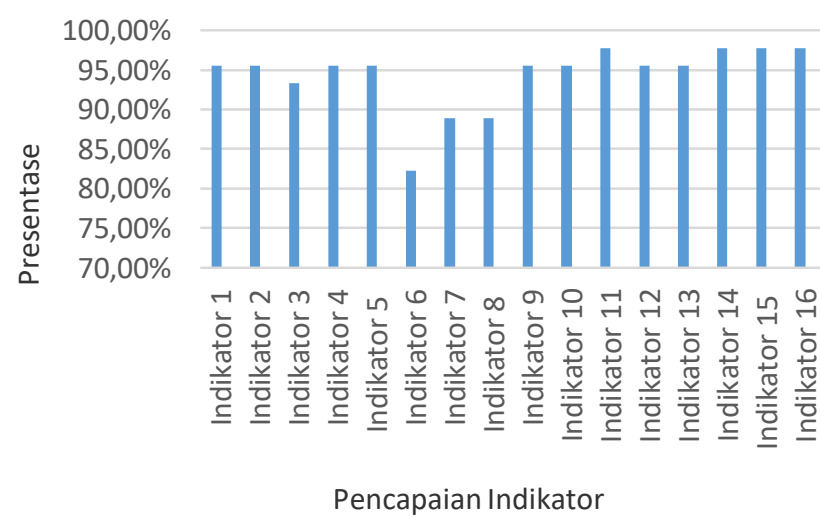

Grafik 4 Respon oleh peserta didik

Melalui nilai rerata pada grafik dapat diketahui bahwa rata-rata presentase tingkat keterbacaan setiap indikator oleh peserta didik SMA N 7 Semarang mencapai lebih dari 81\% dengan tingkat keterbacaan sangat baik.

\section{Evaluation (Evaluasi)}

Alat evaluasi yang digunakan untuk mengumpulkan data pada penelitian ini yaitu instrumen berupa angket skala 5. Angket merupakan kumpulan pertanyaan tertulis untuk mendapatkan informasi yang bersumber dari responden (Arikunto, 2013). Angket yang digunakan pada tahap analyze untuk memperoleh data kebutuhan peserta 
didik adalah angket tertutup. Angket yang digunakan untuk memperoleh penilaian dari validator serta angket yang digunakan pada tahap pada uji kelas kecil adalah jenis angket berbentuk ceklist. Angket juga dilengkapi kolom untuk memberi kesempatan bagi peserta didik memberikan kritik dan saran perbaikan bagi petunjuk praktikum berbasis green chemistry yang diuji cobakan. Menurut Branch (2009), kualitas produk pada tahap evaluasi dapat ditentukan melalui tiga aspek, diantaranya Perception (persepsi), Learning (hasil), dan Performance (sikap). Pada penelitian ini kualitas produk ditentukan melalui aspek perception (persepsi). Persepsi merupakan respon yang diperoleh dari penilaian peserta didik dan guru terhadap petunjuk praktikum berbasis green chemistry yang dikembangkan.

\section{Simpulan dan Saran}

\section{Simpulan}

Berdasarkan pembahasan dapat ditarik beberapa simpulan. Penilaian oleh ahli materi nilai indeks validitas (V) yang didapatkan adalah 0,902 dengan tingkat validitas sangat tinggi. Nilai indeks validitas (V) yang didapatkan dari ahli media adalah 0,984 dengan tingkat validitas sangat tinggi. Dari uji keterbacaaan oleh melalui pengisian angket diperoleh 95,83\% dengan tingkat keterbacaan sangat baik. Respon peserta didik mendapatkan kategori sangat baik dengan presentase $94,29 \%$.

\section{Saran}

Penelitian lebih lanjut untuk mengetahui tingkat keefektifan petunjuk praktikum berbasis green chemistry pada variabel hasil belajar dapat dilaksanakaan pada sekolah yang melaksanakan praktikum menggunakan bahanbahan kimia yang kurang ramah lingkungan.

\section{Daftar Pustaka}

Achmad, R. 2011. Kimia Lingkungan. In: Isu Lingkungan Global. Jakarta: Fakultas Keguruan dan Ilmu Pendidikan Universitas Terbuka.

Bonwell, dkk. Active Learning: Creating Excitement in the Classroom. ASHE-ERIC Higher Education Report No. 1. https://eric.ed.gov/?id=ED336049/. Diunduh 5 Agustus 2019.

Bonweel, dkk. 1991. Active Learning: Creating Excitement in the Classroom.

Branch, S.A. 2009. Instructional Design: The ADDIE Approach. New York: Springer.

Adisendjaja, Y.H. 2010. Pembelajaran Berbasis Praktikum Untuk Meningkatkan Kemampuan Berpikir Kritis Mahasiswa. Jurnal Matematika dan IPA. 1(2): 7.

A'la, M. 2012. Quantum Teaching. Jogjakarta: DIVA Press.

Arifin, M. 2003. Strategi Belajar Mengajar Kimia. Bandung: Program Studi Pendidikan Kimia FPMIPA UPI.

Balram, R. 2017. Pengaruh Metode Praktikum Disertai Feedback Terhadap Hasil Belajar dan Respon Siswa Kelas X pada Materi Larutan. Jurnal Pendidikan dan Pembelajaran. 6(6):3.

Chang, R. 2004. Kimia Dasar Konsep-Konsep Inti. Jilid 1. Edisi 3. Jakarta: Erlangga.

Djamarah, S. dan Aswan Zain. 2002. Strategi Belajar Mengajar. Jakarta: Rineka Cipta.

Faturrohman, Pupuh \& Sobri Sutikno. 2011. Strategi Belajar Mengajar Melalui Penanaman Konsep Umum \& Konsep Islami. Bandung: PT Refika Aditama.

Hammond, L.D, dkk. 2019. Implications for Educational Practice of the Science of Learning and Development. Applied Developmental Science, DOI: 10.1080/10888691.2018.1537791. : 
Diunduh di

https://doi.org/10.1080/10888691.201

8.1537791/tanggal 5 Agustus 2019.

Hendryadi. 2014. Content Validity (Validitas Isi). Teorionline Personal Paper. 1:3.

Iqbal, S.A., dan Neelofar iqbal. 2011. Textbook of Green Chemistry. New Delhi: Tilak Wasan Discovery Publishing House PVT.LTD.

Junaedi, Dedi. 2018. Desain Pembelajaran Model ADDIE. Diunduh di https://www.academia.edu/ tanggal 24 April 2019.

Kandamby, G.T.C. 2019. Effectiveness of laboratory practical for Students' Learning. International Journal for Innovation Education and Research. $7(3) ; 222$.

Keenan, C.W., Donald C.K,. \& Jesse H.W. Ilmu Kimia Untuk Universitas. Edisi 6 Jilid 1. Jakarta: Erlangga.

Lestari, E.S. 2017. Penggunaan Media Laboratorium Virtual Untuk Meningkatkan Pengetahuan Prosedural Siswa Pada Pokok Bahasan Sistem Ekskresi. Skripsi. Bandung: Fakultas Keguruan dan Ilmu Pendidikan Universitas Pasundan.

Mackenbach, J.P. 2007. Global Environmental Change and Human Health: A Public Health Research Agenda. Journal of Epidemiology \& Community Health. 61(2): 92.

Majid, Abdul \& Chaerul Rochman. 2014. Pendekatan Ilmiah Dalam Implementasi Kurikulum 2013. Bandung: PT Remaja Rosdakarya.

Manahan, S.E. 2005. Green Chemistry and The Ten Commandments of Sustainability. Columbia: ChemChar Research, Inc.

Mattsson, K., dkk. 2015. Nano-Plastics In The Aquatic Environment. Environmental Science: Processes and Impacts.

60

Copyright (C) 2019 JEC | ISSN 2715-3029 (p) 2685-4880 (e)

Volume 1, Nomor 2, 2019
Meyhandoko, Adityas. 2013. Pengembangan Petunjuk Praktikum Konstektual Dengan Pemanfaatan Kondisi Lingkunga Lokal Dalam Pembelajaran Materi Pencemaran Di SMA N 2 Rembang. Skripsi. Semarang: Fakultas Matematika Dan Ilmu Pengetahuan Alam Universitas Negeri Semarang.

Mulyatun. 2015. Kimia Dasar (Buku Panduan Kuiah Mahasiswa Biologi). Cetakan I. Semarang: CV.Karya Abadi Jaya.

Muthi'ah, Siti. 2015. Pengembangan Modul Praktikum Kimia Berbasis Green Chemistry pada Materi Kelarutan dan Hasil Kali Kelarutan di SMA Negeri 71 Jakarta. Skripsi. Jakarta: Program Studi Pendidikan Kimia, Jurusan Kimia, FMIPA, UNJ.

Nazilla, Nurul., dkk. 2017. Analisis Pelaksanaan Praktikum Pada Pembelajaran Biologi Kelas X MAN Tanjungpinang Tahun Ajaran 2016/2017. Jurnal Universitas Maritim Raja Ali Haji. 1(1):3.

Nurbaity. 2011. Pendekatan Green Chemistry Suatu Inovasi Dalam Pembelajaran Kimia Berwawasan Lingkungan. Jurnal Riset Pendidikan Kimia. 1(1): 17.

Ojediran, I. Ayodele. 2014. Impact of Laboratory-Based Instructional Intervention on the Learning Outcomes of Low Performing Senior Secondary Students in Physics. Article in Creative Education. Creative Education. 5:197.

Penuel, W.R., \& Fishman, B.J. 2012. Large-scale science education intervention research we can use. Journal of Research in Science Teaching. 49(3), 281.

Peratiwi, N.K.Ana., dkk. 2014. Buku Pedoman Praktikum Kimia Ramah Lingkungan Untuk Pembelajaran Kimia SMA. EJournal Kimia Visvitalis Universitas Pendidikan Ganesha Jurusan Pendidikan Kimia. 2(1): 68. 
Ralph, H.P., dkk. 2007. Kimia Dasar Prinsipprinsip dan Aplikasi Modern. Edisi 9 Jilid I. Jakarta: Erlangga.

Retnawati, Heri. 2016. Analisis Kuantitatif Instrumen Penelitian (Panduan Peneliti, Mahasiswa, dan Psikometrian). Yogyakarta: Parama Publishing.

Redhana, I.W. 2014. Kimia Hijau Dalam Praktikum Laju Reaksi. Skripsi. Denpasar: Fakultas Matematika dan Ilmu Pengetahuan Alam Universitas Pendidikan Ganesha.

Rismawati. 2012. Pengembangan Penuntun Praktikum Alternatif Sederhana Sebagai Pendamping Penuntun Praktikum Standar Kimia SMA Kelas XI. Tesis. Medan: Program Pascasarjana Universitas Negeri Medan.

Suprihatiningrum, Jamil. 2012. Strategi Pembelajaran Teori Dan Aplikasi. Jogjakarta: Ar-Ruzz Media.

Suryaningsih, Yeni. 2017. Pembelajaran Berbasis Praktikum Sebagai Sarana Siswa Untuk Berlatih Menerapkan Keterampilan Proses Sains Dalam Materi Biologi. Jurnal Bio Educatio. 2(2): 49-57.

Ural, Evrim. 2016. The Effect of Guided-Inquiry Laboratory Experiments on Science Education Students' Chemistry Laboratory Attitudes, Anxiety and Achievement. Journal of Education and Training Studies. 4(4). 217-227.

Warner, J.C., Amy S. Cannon., \& Kevin M. Dye. 2004. Green Chemistry. Environmental Impact Assessment Review.1(24): 776.

Widjajanti, Endang., E. Rohaeti., \& Isana SYL. 2010. Penerapan Praktikum Kimia Bermuatan Life Skills Sebagai Upaya Mempersiapkan Calon Guru Yang Berkarakter. Diunduh di https://eprints.uny.ac.id/ tanggal 28 Juli 2019.

Wulandari, Vindri .C.P., Masjhudi., \& Balqis. 2013. Penerapan Pembelajaran Berbasis Praktikum Untuk Meningkatkan Keterampilan Proses
Sains dan Penguasaan Konsep Siswa Kelas XI IPA 1 di SMA Muhammadiyah 1 Malang. Diunduh di http://jurnalonline.um.ac.id/ tanggal 27 April 2019.

Yakina., Tuti Kurniati., \& Raudhatul Fadhilah. 2017. Analisis Kesulitan Belajar Siswa pada Mata Pelajaran Kimia Kelas X di SMA Negeri 1 Sungai Ambawang. $A r$ Razi Jurnal Ilmiah. 5(2):2.

Zhong, G. 2014. Training of Scientific thinking Methods In Teaching of Inorganic and Analytical Chemistry. Journal of Chemical and Pharmaceutical Research. 6(7):1503. 